\section{PP3-041 腎癌に対する生検の病理学的检討}

昭和大学藤が丘病院泌尿器科 ${ }^{1}$, 昭和大学泌尿器科 ${ }^{2}$, クイーンズメディカルセンター ${ }^{3)}$

井上 克己 ${ }^{1)}$, 池内 隆夫" ${ }^{12}$ 吉田 英機2),

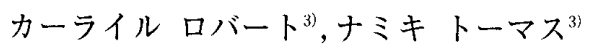

【目的】腎腫場の診断は画像診断で十分であり、生検の必要は ないとされている。そこで腎癌の生検と手術病理組織を比較 し、病理学的意義について梌討した。対象扔よび方法】術前 に経皮針生検が行われた 21 例を対象とした。生検は CT ガ イド下に $20 \mathrm{G}$ 針で 1 本採取した。生検診断による組織型、 gradeを後の手術で得られた病理組織と比較した。grade は Fuhrman gradeを用いた。【結果】組織型は淡明型 RCC16 例、乳頭状型 RCC3 例、嫌色素型 RCC1 例、オンコサイトー マ 1 例。平均腫瘍長径 $6.2 \mathrm{~cm}$ 。grade は $\mathrm{g} 1 、 \mathrm{~g} 2 、 \mathrm{~g} 3 、 \mathrm{~g} 4$ がそれ ぞれ 2 例、 9 例、 7 例、 2 例であった。生検組織は平均 $8.0 \mathrm{~mm}$ 。 このうち腫瘍は $2.9 \mathrm{~mm} 。 21$ 生検中 19 例で生検組織は RCC またはオンコサイトーマと診断が可能であったが、1例は腫 揚組織が少なく診断不能、1 例は腫瘍組織を含むものの、 RCC との診断には至らなかった。生検組織では乳頭状 RCC および嫌色素型 RCC を淡明型 RCC と鑑別することができ なかった。grade は $61 \%$ の生検組織で腎摘組織より低い gradeであった。生検組織が腎摘組織より高い grade の例は なかった。考察】20G1 本の針生検は、90\%が腎癌の診断が 可能な量の腫瘍組織を含んでいた。しかし、組織型の診断は 困難で、低い gradeに診断される傾向にあった。

\section{PP3-042 早期腎臓癌に対する手術療法の選択}

\section{都立駒込病院泌尿器科}

田中 雅彦, 篠原 充, 山川 潤, 荒木 彰弘, 宗像昭夫 近年検診や他疾患の精查に伴う CT や腹部エコーの使用 が增加し、早期に発見される腎癌が増えてきている。さ らに、従来の根治的腎摘除術のほかに患者の Q. O.Lを考 慮した術式が盛んに行われるようになっている。開腹・ 腹腔鏡および全摘・部分切除それらの組み合わせによる 手術法が考案されている。各施設において様々な取り組 みがなされていると考えられるが、当施設では 2001 年 1 月から腹腔鏡手術を導入し、2003 年1月よりマイクロ ターゼの使用を開始した。早期腎癌に対する術式の選択 肢が增えたことで、その適応が問題となる。我々は各手 術方法につき侵襲・合併症・手技難度・習熟度等を説明 した上で患者自身に術式を選択してもらっている。今回 2001 年 1 月から 2003 年 8 月までの当院における早期腎 癌に実際に施行された術式について報告し、その問題点 を検討した。その結果を今後の術式選択の標準化に役立 てたいと考え報告する。

\section{PP3-043 根治的腎摘除術における副腎摘出の必 要性についての考察}

\section{名古屋第二赤十字病院䎵尿器科}

山田 浩史, 石田 亮, 錦見 俊徳, 横井圭介, 小林弘明 根治的腎摘出術において副腎を同時に摘出することは、 腎癌の根治性を高める意味において必要とされ現在まで 施行されてきた。しかし、その再発転移率において疑問 視する報告が多数見受けられるのもまた事実である。今 回我々は、1997年 5 月 28 日より 2000 年 8 月 18 日まで の期間に腎細胞癌の診断にて根治的腎摘除術を施行され た 36 例（平均年齢 73 歳、男性 23 例、女性 13 例）を対 象としてその副腎転移及び再発予後について考察検討し た。平均腫瘍サイズ $42 \mathrm{~mm}$ 、平均個数 1 個、発生部位 (上 極 16 例、中部 10 例、下極 10 例）右腎 19 例、左腎 17 例。pT1a 13 例、pT1b 15 例、pT2 3 例、pT3a 3 例、pT $3 \mathrm{~b} 1$ 例、pT4 1 例。術中副腎摘出施行された症例は 30 例、温存された症例は 6 例だったが、部位、サイズ、異 型度及びステージにかかわらず、副腎転移のあった症例 は皆無であった。また、全症例の平均観察期間は 43.1 ケ月であり、うち死亡例は 3 例であり多臓器への転移が 死亡原因であった。(副腎周囲の局所再発は認められな かった。)根治的腎摘除術施行時における副腎摘除の指標 及びその必要性につき若干の文献的考察を加え報告す る。

\section{PP3-044 Benign Complicated Renal Cyst との 鑑別が困難な Cystic Renal Cell Car- cinoma の画像診断について}

\section{獨協医科大学泌尿器科", 獨協医科大学放射線科 ${ }^{21}$ 增田 聡雅", 斉木 名執 23 , 山口 佳志", 釜井 隆男"), 本田 幹彦",, 山西 友典 ${ }^{11}$, 吉田 謙一郎1}

【目的】Cystic RCC の画像診断は Complicated Cyst との 鑑別が重要であり、CT を基にした Bosniak 分類の有用 性が報告されている。しかし、CT 上 Complicated Cyst と診断される症例のなかに、Cystic RCC が存在すること が示唆されている。今回 Complicated Cyst との鑑別が困 難であった Cystic RCC の CT, US, MRI 所見について検 討した。【方法】 Complicated Cyst との鑑別が困難であっ た Cystic RCC5 例を対象とし、Bosniak 分類を用いて CTにて category 分類し、US, MRI 補助診断として評 洒した。【結果】 4 例が categoryIII に属し、US, MRI 所見 と併せ Cystic RCC と診断された。1 例は categoryIIに 属し CT 上 Complicated Cystが示唆されたが、USにて solid mass, 造影 MRI で壁が一部造影されたため、Cystic RCC と術前診断された。手術治療て確定診断を得た。 【結論】Cystic RCC の画像診断に Bosniak 分類が有用で あるが、鑑別困難な Complicated Cystic Renal Mass の画 像診断は US, MRI 補助診断として、総合的に判断する ことが望ましい。 